\title{
Badania laboratoryjne określające wzrost potencjału parafinowania wraz ze spadkiem temperatury
}

\begin{abstract}
W publikacji rozważono tematykę wpływu ciśnienia i temperatury na wytrącanie się osadów parafinowych z płynów złożowych. Wymieniono ważniejsze metody badawcze służące do określania temperatury depozycji stałej fazy parafinowej (wax appearance temperature - WAT). Omówiono metody pozwalające na wyznaczenie krzywej wytrącania parafiny - WPC (wax precipitation curve). Wykorzystując odpowiednio zmodyfikowaną aparaturę PVT, określono temperaturę początku wytrącania się parafiny (WAT), poniżej której na specjalistycznym filtrze wychwycono stałą fazę parafinową w różnych temperaturach. Na podstawie przeprowadzonych eksperymentów wyznaczona została granica rozdzielająca obszar parafinowy (występowanie parafin w fazie stałej) od obszaru bez parafiny. Pomiary ilości parafiny z wykorzystaniem filtra pozwoliły na wyznaczenie krzywej WPC, dzięki której otrzymujemy dodatkowe dane o ilości wytrąconego osadu parafinowego poniżej WAT. Szczególną zaletą opisanych badań jest możliwość wykonania pomiarów w szerokim zakresie ciśnień oraz nasycenie badanej próbki gazem złożowym, co pozwala na uzyskanie takiej próbki ropy, jaka występuje w rzeczywistych warunkach eksploatacyjnych. Większość znanych na świecie sposobów badań nie umożliwia takiego przygotowania próbki oraz pomiaru pod wpływem ciśnienia, tym samym otrzymane wyniki obarczone są błędem. Aspektem ekonomicznym stosowania omawianego sposobu jest możliwość prowadzenia eksploatacji z zachowaniem optymalnych warunków ciśnienia i temperatury, w których badane zjawisko nie zachodzi lub jest minimalne. Znajomość przebiegu krzywej wytrącania parafin (WPC) jest niezbędna do wybrania optymalnej, w danych warunkach, metody przeciwdziałania powstawaniu wytrąceń parafinowych blokujących przepływ mediów złożowych. Opracowany sposób pomiaru daje możliwość określenia skuteczności działania specjalistycznych inhibitorów parafin i asfaltenów oraz wyznaczenia ich optymalnego dawkowania. Takie podejście pozwala zarówno na ograniczenie kosztów, jak też na zminimalizowanie ryzyka zablokowania przepływu ropy z jednoczesnym zachowaniem ciągłości produkcji.
\end{abstract}

Słowa kluczowe: parafiny, WAT, WPC, depozycja stałej fazy parafinowej.

\section{Laboratory studies for the determination of the increase in the wax formation potential associated with the decrease in the temperature}

In this paper, the issue of pressure and temperature influence on the paraffin wax deposition in reservoir fluids was raised. Typical research methods for determining wax appearance temperature (WAT) were briefly characterized. Methods for the determination of wax precipitation curve (WPC) were discussed. Using the appropriately modified PVT apparatus the wax appearance temperature was determined, below which a solid waxy phase at various temperatures was captured on a specialized filter. On the basis of the research carried out, the boundary separating the wax deposition hazard zone (the occurrence of solid paraffin waxes) from the zone without wax was determined. Measurements of the amount of wax allowed to determine the WPC curve, thanks to which the additional data concerning the amount of solid wax deposited below WAT were obtained. A special advantage of the method is its ability to perform measurements in a wide range of pressures and the saturation of the tested sample with reservoir gas, which allows obtaining a sample of crude oil that occurs in real operating conditions. Most of the known research methods in the world do not allow for such sample preparation and measurement under pressure, thus the results obtained are flawed to a certain extent. The economic aspect of the discussed method is the ability to conduct operations while maintaining optimal pressure and temperature conditions in which the studied phenomenon does not occur or is minimal. Knowledge of the wax precipitation curve - WPC is necessary to select the optimal method for counteracting the formation of paraffin precipitates, which are blocking the flow of reservoir fluids for given conditions. The developed method of measurement gives the possibility to determine the effectiveness of specialist paraffin and asphaltene inhibitors and to determine their optimal dosage. This approach allows to reduce costs as well as minimize the risk of blocking oil flow while maintaining production continuity.

Key words: paraffins, WAT, WPC, paraffin wax deposition. 


\section{Wprowadzenie do zjawisk formowania się osadów parafinowych}

Proces depozycji parafiny z płynów złożowych, szczególnie $\mathrm{w}$ głębokich odwiertach, jest niejednokrotnie przyczyną wstrzymania wydobycia ropy i gazu. Przy opracowywaniu sposobów zapobiegania wytrącaniu parafiny z płynów złożowych w czasie ich eksploatacji - niezbędne jest określenie warunków depozycji stałej fazy parafinowej (WAT - wax appearance temperature). Znajomość temperatury początku wytrącania parafin jest niezbędna do określenia optymalnej w danych warunkach metody przeciwdziałania powstawaniu wytrąceń parafinowych, blokujących przepływ mediów złożowych [12]. Uzupełnieniem tych badań jest wykreślenie krzywej WPC (wax precipitation curve), dostarczającej danych o ilości wytrąconego osadu parafinowego w dowolnej temperaturze poniżej WAT.

\section{Ogólna charakterystyka parafin}

Mianem parafin określa się grupę węglowodorów nasyconych, przy czym istnieją istotne różnice w interpretacji składu tej grupy w zależności od kontekstu:

- w chemii organicznej termin ten odnosi się do alifatycznych węglowodorów nasyconych (homologów metanu) o ogólnym wzorze: $\mathrm{C}_{\mathrm{n}} \mathrm{H}_{2 \mathrm{n}+2}$, posiadających od 1 do 61 atomów węgla w cząsteczce, występujących w fazie gazowej, ciekłej oraz stałej,

- w żargonie naftowym parafinami nazywane są mieszaniny n-alkanów, izoalkanów i cykloalkanów w fazie stałej. Do tej grupy zaliczyć możemy również woski, osady zawierające 17 lub więcej atomów węgla w cząsteczce, wytrącające się z mediów złożowych w procesie ich wydobycia. Parafinowanie to wytrącanie się z ropy naftowej osadów na ściankach armatury napowierzchniowej. Proces ten generuje znaczne trudności i zagrożenia podczas eksploatacji, transportu oraz procesów przeróbki węglowodorów. Problem dotyczy nie tylko złóż ropnych i kondensatowych, ale również gazo- wych [10,13]. Wytrącająca się parafina może osadzać się na ściankach orurowania, zmniejszając przepływ. Niejednokrotnie prowadzi to do całkowitego wstrzymania wydobycia na skutek zaczopowania rurek wydobywczych, żerdzi pompowych, jak również rurociągów napowierzchniowych. Parafinowanie przyczynia się do generowania znacznych strat finansowych związanych ze zmniejszeniem wydobycia, zwiększeniem zapotrzebowania energii na przetłaczanie oraz koniecznością wykonywania kosztownych zabiegów serwisowych $[2,13,16]$.

Wyróżniamy dwa rodzaje wosków wytrącających się z płynów złożowych:

- woski makrokrystaliczne składające się głównie z n-alkanów o masie cząsteczkowej od 300 do 600, krystalizujące w formie płaskich/płytkowych struktur,

- woski mikrokrystaliczne lub amorficzne tworzone głównie przez izo- i cykloalkany o masach cząsteczkowych w zakresie od 300 do 2500, krystalizujące w formie małych igiełkowych struktur [7, 15].

\section{Przegląd metod badawczych do określania temperatury WAT}

Temperatura WAT, odnosząca się do pierwszych oznak wytrącania się parafiny, jest najważniejszym parametrem określającym podatność płynów złożowych na depozycje osadów parafiny. Przez wiele lat badań prowadzonych w tym kierunku wypracowano szereg metod badawczych mających na celu jak najdokładniejsze określenie temperatury WAT.

Wymienione poniżej metody zostały dokładnie opisane we wcześniejszej publikacji autorów [20]:

- metoda ,zimnego palca” [3, 13],

- metoda ASTM Standard D-2500 [5, 8, 9, 13],

- metoda fotometryczna [6],
- metoda optycznego mikroskopu polaryzacyjnego - CPM (cross polarized microscope) [8, 13, 18],

- metoda fourierowskiej spektroskopii w podczerwieni FT-IR (Fourier-transform infrared spectroscopy) [8],

- metoda termiczna różnicowego kalorymetru skaningowego - DSC (differential scanning calorimetry) [8],

- metoda objętościowego kurczenia parafiny w trakcie krzepnięcia [11, 13],

- metoda pomiarów oporów filtra w warunkach dynamicznych [13],

- metoda zmiany lepkości w funkcji temperatury [13].

\section{Przegląd metod badawczych do określania WPC}

Wyznaczenie temperatury WAT oparte jest na fizycznych zmianach badanej ropy wynikających ze zmiany stanu skupienia parafin z ciekłego na stały. Znajomość warunków wytrącania stałej fazy parafinowej nie daje informacji o jej ilości, która w trakcie eksploatacji ma bardzo istotne znaczenie. Wyznaczając WPC, otrzymujemy dodatkowe dane o ilości 
wytrąconego osadu parafinowego w dowolnej temperaturze (rysunek 1). Poniżej opisano kilka wypracowanych metod eksperymentalnych pozwalających na wyznaczenie WPC.

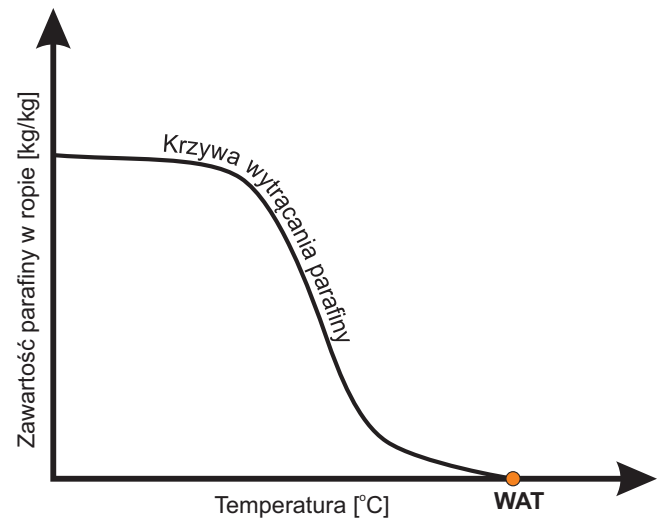

Rys. 1. Typowy przebieg WPC - krzywej wytrącania parafiny [8]

\section{Metoda termiczna różnicowego kalorymetru}

skaningowego (differential scanning calorimetry - DSC)

W praktyce przemysłowej jest to najczęściej stosowana metoda wyznaczenia WAT oraz WPC. Metody termiczne wykorzystują fakt, że precypitacja parafiny zachodzi z wydzielaniem ciepła, natomiast rozpuszczanie powoduje jego absorbcję. Jest to ściśle związane z ciepłem topnienia, które dla parafin wynosi $155 \pm 8,4 \mathrm{~kJ} / \mathrm{kg}$. Kalorymetr wychwytuje ciepło uwolnione z próbki podczas krystalizacji, na podstawie którego określa się początek wytrącania parafiny (WAT). Samo schładzanie próbki, bez krystalizacji parafin, również generuje ciepło, które jest rejestrowane przez kalorymetr. By oddzielić ciepło związane z ochładzaniem próbki od tego, które wydziela się podczas krystalizacji, należy ustalić linię odniesienia (tła). Wyznacza się ją przez połączenie punktów początkowych i końcowych na wykresie zależności wielkości strumienia cieplnego od temperatury [14].

Skumulowane ciepło uwolnione od początku precypitacji parafiny do określonej temperatury można uzyskać przez zintegrowanie obszaru zamkniętego przez termogram i linię odniesienia, jak pokazano na rysunku 2. To skumulowane wydzielane ciepło $(q \mathrm{WAT} \rightarrow T)$ jest ściśle związane z ilością wosku, który wytrącił się od WAT do określonej temperatury [4].

Określenie ilości wytrąconej parafiny wymaga dwóch założeń:

- entalpia krystalizacji wosków jest stała (nie zmienia się w odniesieniu do temperatury),

- entalpia krystalizacji ma wartość $200 \mathrm{~J} / \mathrm{g}$.

Oba te założenia mogą być obarczone błędem, a tym samym wprowadzić niepewność przy określeniu rzeczywistej zawartości zdeponowanej parafiny. Często pomiar taki wymaga zbadania całkowitej zawartości parafiny, a następnie dopasowania wartości WPC.

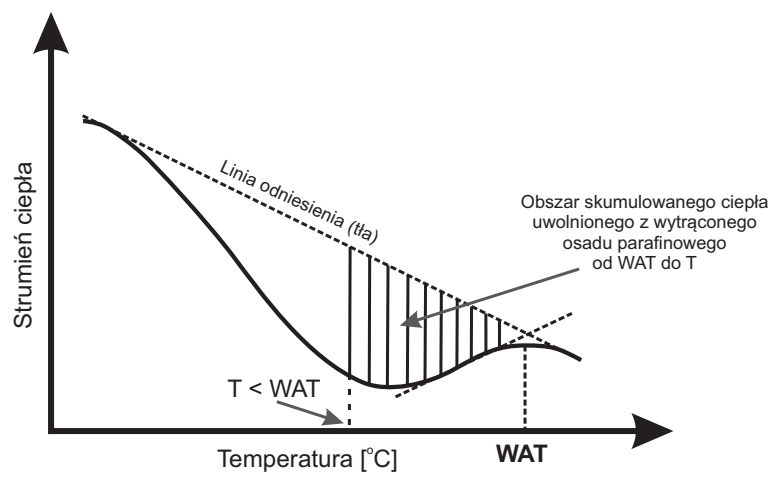

Rys. 2. Określenie ilości wytrąconej parafiny metodą DSC [8]

\section{Metoda z wykorzystaniem jądrowego rezonansu magnetycznego NMR}

Oznaczanie WPC przez NMR opiera się na różnicy zachowań relaksacyjnych protonów w stanie stałym i ciekłym. Po wzbudzeniu protonu przez impuls o częstotliwości radiowej następuje jego relaksacja do stanu równowagi przez emitowanie nadwyżki energii zgodnie ze stanem równowagi jego otoczenia, powodując zanik intensywności NMR (swobodny zanik indukcji - FID).

Protony w stanie stałym mają krótsze czasy relaksacji. Intensywność NMR spowodowana przez proton w fazie stałej szybko ulega rozproszeniu do nieznaczącej wielkości. Protony w stanie ciekłym w porównaniu z protonami w stanie stałym mają dłuższe czasy relaksacji, przez co ich FID posiada stosunkowo długi ,ogon”.

W stanie zawieszenia stałej fazy parafinowej w próbce ropy relaksacje protonów w fazie stałej i ciekłej składają się na swobodny zanik indukcji FID, a tym samym całkowity FID jest kombinacją zarówno FID fazy stałej, jak i FID fazy ciekłej. W przypadku typowej zależności FID w funkcji czasu dla mieszaniny stałej fazy parafinowej zawieszonej w ropie (rysunek 3) obserwuje się szybki FID protonu bezpośrednio po wzbudzeniu dla fazy stałej. Po zaniku sygnału protonu w fazie stałej do znikomego poziomu można zaobserwować

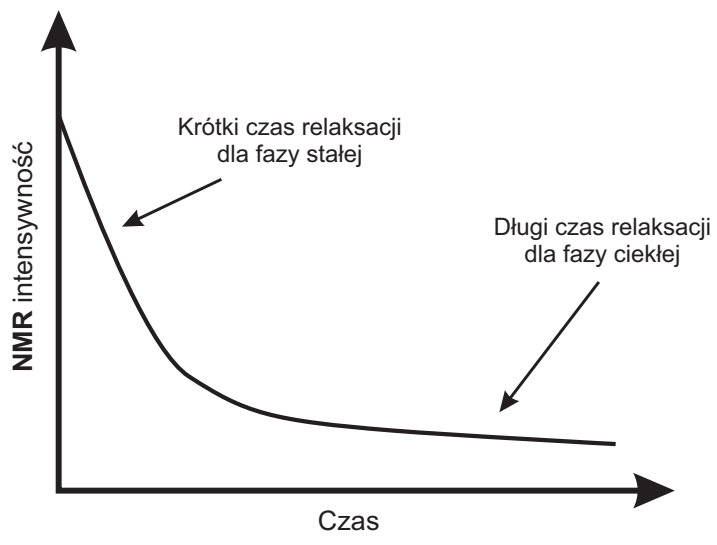

Rys. 3. Reprezentatywny NMR FID mieszaniny stałej fazy parafinowej z ropą [8] 
długi „ogon” ze względu na stosunkowo wolniejszy FID protonów w fazie ciekłej.

W reprezentatywnym eksperymencie NMR do oznaczania WPC - natężenie NMR tej samej próbki mierzy się dwukrotnie: pierwszy raz bezpośrednio po impulsie częstotliwości radiowej $\left(t=t_{1}\right)$ i drugi, gdy FID stanu stałego osiągnie wartość równą zero $\left(t=t_{2}\right)$.

W momencie gdy natężenie wywołane przez proton w fazie stałej szybko zanika do pomijalnego poziomu, drugie natężenie NMR zawiera jedynie udział fazy ciekłej, podczas gdy pierwsze natężenie zawiera zarówno udział fazy ciekłej, jak i stałej. Te dwa natężenia mogą być wykorzystane do obliczenia frakcji stałej w próbce na podstawie następującego równania.

Jeżeli $I\left(T, t_{1}\right)$ i $I\left(T, t_{2}\right)$ będą dwoma całkowitymi natężeniami przy $t_{1}$ i $t_{2}$, to $I\left(T, t_{1}\right)$ i $I\left(T, t_{2}\right)$ można wyrazić jako kombinację liniową składnika w stanie stałym i składnika w stanie ciekłym, jak przedstawiono w poniższym równaniu [8]:

$t_{1}: I\left(s, t_{1}\right)+I\left(l, t_{1}\right)=I\left(s, t_{1}\right)$

$t_{2}: I\left(s, t_{1}\right) \exp -\frac{t_{2}}{\tau_{s}}+I\left(l, t_{1}\right) \exp -\frac{t_{2}}{\tau_{1}}=I\left(T, t_{2}\right)$

Jako że intensywności sygnałów NMR: $I\left(s, t_{1}\right), I\left(l, t_{1}\right), I\left(s, t_{2}\right)$ i $I\left(l, t_{2}\right)$ są proporcjonalne do ilości zdeponowanej parafiny i cieczy/ropy, można określić względną ilość stałej fazy parafinowej i cieczy/ropy, rozwiązując powyższy układ równań.

Przy zastosowaniu techniki NMR pomiar zawartości ciała stałego w określonej temperaturze trwa około 10 sekund. Pomiary NMR posiadają bezwzględne odchylenie standardowe $\pm 0,2 \%$ całkowitej masy stałej fazy parafinowej zawartej w próbce.

\section{Metoda z wykorzystaniem FT-IR}

Długołańcuchowe alkany absorbują światło podczerwone (IR) o długości fali $\sim 7201 / \mathrm{cm}$. W mieszaninie zarówno stałych, jak i ciekłych alkanów intensywność absorbancji IR jest liniową kombinacją udziału alkanów w fazie stałej i ciekłej.

Intensywność absorbancji alkanu w fazie stałej jest o 50\% większa niż alkanu w fazie ciekłej lub amorficznej [19]. W konsekwencji, gdy krystaliczny wosk tworzy się w czasie ochładzania, obserwuje się znaczny wzrost intensywności ze względu

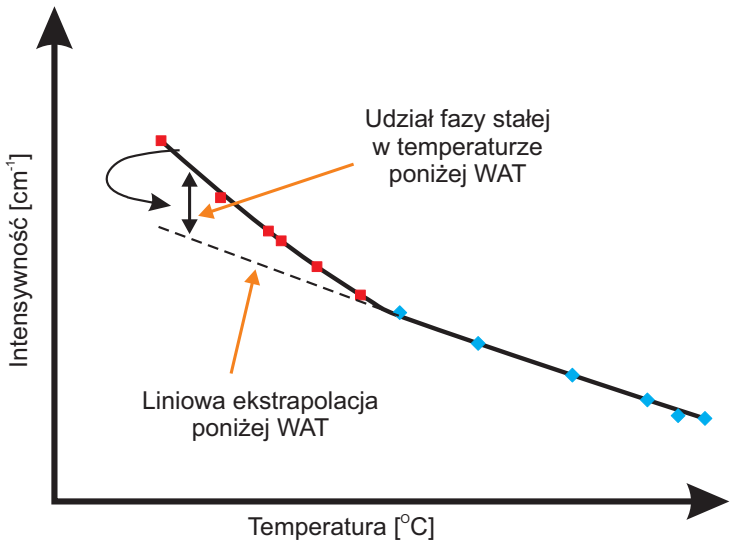

Rys. 4. Zmiana natężenia światła podczerwonego FT-IR ropy naftowej w funkcji temperatury [17]

na udział stałej fazy parafinowej. Jak pokazano na rysunku 4, powyżej WAT intensywność wynika wyłącznie $\mathrm{z}$ absorbancji fazy ciekłej.

Tak więc liniowa ekstrapolacja natężenia poniżej WAT, oznaczona linią przerywaną na rysunku 4, zapewnia oszacowanie udziału fazy ciekłej w temperaturach poniżej WAT. Różnica między zmierzoną intensywnością a ekstrapolacją jest wprost proporcjonalna do ilości fazy stałej zawartej w mieszaninie. Różnica ta może być zatem wykorzystana do obliczenia ilości wytrąconej fazy stałej. Alcazar-Vara i Buenrostro-Gonzalez [1] oraz Roehner i Hanson [17] przedstawiają dwa reprezentatywne badania dotyczące zastosowania FT-IR w pomiarach WPC.

\section{Metoda wytrącania frakcjonalnego}

Próbka uprzednio podgrzanej, rozgazowanej ropy (50 g) jest chłodzona przez 24 godziny w kriostacie do temperatury nieznacznie przekraczającej spodziewaną temperaturę WAT. Następnie ropę filtruje się przez kolejne 2 godziny, używając filtra z włókna szklanego. Odfiltrowana faza stała jest przepłukiwana acetonem w celu zebrania resztek ropy znajdującej się na jej powierzchni. Pozostała ciecz zostaje użyta do następnej precypitacji, którą wykonuje się w kolejnych krokach, obniżając temperaturę o $3 \div 5^{\circ} \mathrm{C}$. Cała procedura powtarzana jest $4-5$-krotnie, co pozwala na obliczenie ilości parafiny krystalizującej w każdej $\mathrm{z}$ badanych temperatur i wykreślenie krzywej wytrącania (WPC). Na podstawie krzywej wyznacza się temperaturę WAT [4].

\section{Badania laboratoryjne}

Badania temperatury początku wytrącania parafiny prowadzono z wykorzystaniem bezrtęciowej aparatury PVT do badań właściwości fazowych płynów złożowych. Dla realizacji wymienionych badań zestaw PVT został odpowiednio rozbudowany dodatkowo o szereg połączeń wysokociśnieniowych oraz układ chłodzący (kriostat) służący do utrzymywania zadanej temperatury.
Głównym elementem aparatury przy określaniu początkowych warunków ciśnienia i temperatury wytrącania parafiny był wiskozymetr kapilarny. Modernizacja aparatury polegała na wymontowaniu z łaźni termostatycznej aparatury PVT wiskozymetru i zamontowaniu go w łaźni kriostatu wypełnionej roztworem glikolu etylenowego. Kriostat dodatkowo umożliwił precyzyjną regulację temperatury przepływającej próbki płynu 
złożowego. Zmiana umiejscowienia wiskozymetru pozwalała na utrzymywanie stałej temperatury badanej próbki ropy w komorach badawczych aparatury PVT (powyżej WAT) przy jednoczesnej możliwości obniżania temperatury próbki przepływającej przez wiskozymetr kapilarny (rysunek 5). Takie podejście pozwoliło na wyeliminowanie ryzyka wytrącenia osadu już w komorach ciśnieniowych, co mogłoby spowodować popełnienie znaczących błędów w określeniu warunków wytrącania parafin $\mathrm{z}$ badanej ropy. Do badań warunków depozycji stałej fazy parafinowej użyto ropy pobranej z separatora odwiertu Buszewo-1 i ropy Lubiszyna-3k bis.

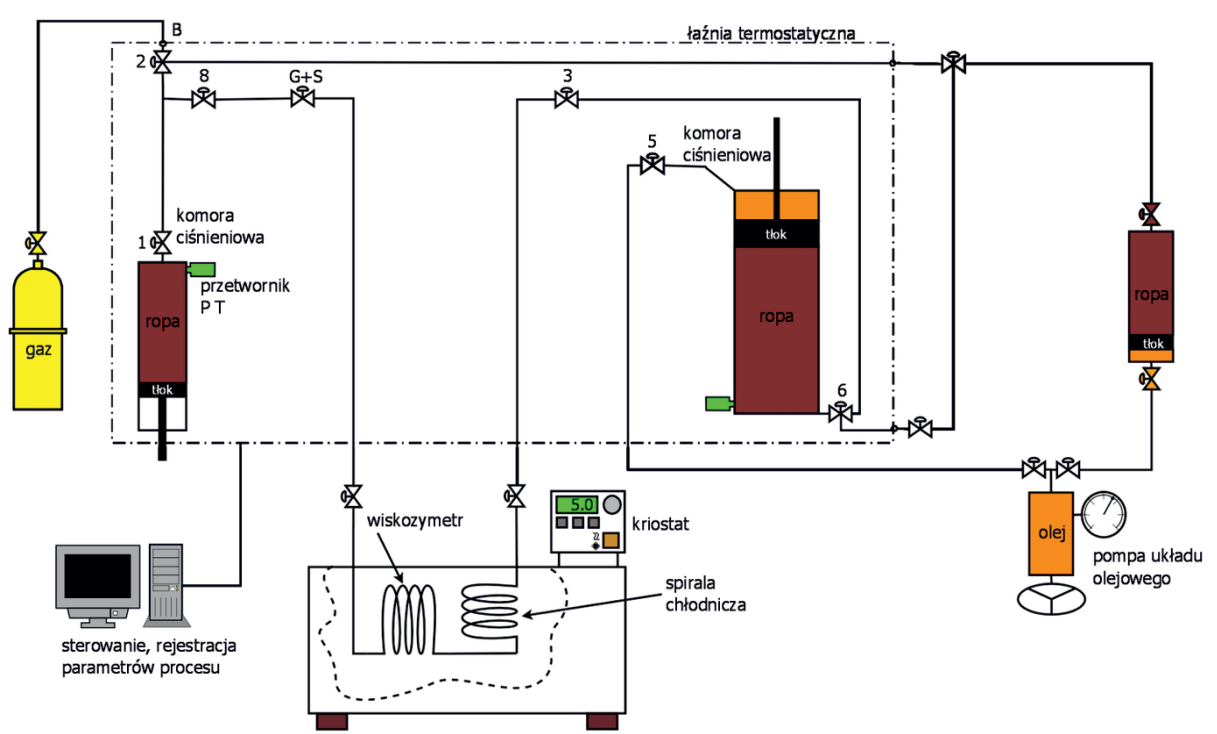

Rys. 5. Aparatura PVT dostosowana do określenia warunków wytrącania stałej fazy parafinowej

\section{Ropa i gaz separatorowy - badanie warunków depozycji stałej fazy parafinowej}

Na obu pobranych próbkach ropy wykonano dwie serie badawcze. W pierwszej serii przeprowadzono pięć eksperymentów. Założono, że pierwszy eksperyment przeprowadzony zostanie dla próbki ropy martwej (nienasyconej gazem). W kolejnych badaniach próbka będzie nasycana gazem w krokach co 50 bar, aż do uzyskania $P_{\text {nas }}=200$ bar.

W drugiej serii badawczej wykonano cztery eksperymenty. Przed każdym badaniem przeprowadzano rekombinację około $300 \mathrm{~cm}^{3}$ próbki do ciśnienia nasycenia 200 bar w temperaturze $45^{\circ} \mathrm{C}$. Założono, że każdy eksperyment przeprowadzony zostanie na próbkach ropy o tej samej wartości ciśnienia nasycenia. W kolejnych badaniach próbka będzie sprężana do wyższego ciśnienia w krokach co 50 bar do uzyskania $P_{\text {bad }}=400$ bar.
Na poniższych wykresach przedstawiono przykładowy przebieg wykonanych eksperymentów do wyznaczenia WAT. Na pierwszym zobrazowany został wpływ temperatury próbki ropy na opór przepływu. Na drugim wykresie przedstawiono przyrost oporów przepływu przeliczony na jeden stopień Celsjusza w funkcji temperatury. W obu przypadkach zaznaczono wartość temperatury WAT.

W tablicy 1 zebrano główne wyniki badań, a na rysunkach 6 i 7 przykładowy przebieg jednego z eksperymentów.

Na rysunku 8 przedstawiono wizualnie wyniki badań warunków depozycji stałej fazy parafinowej dla dwóch próbek ropy, pochodzących odpowiednio z odwiertów Buszewo-1 oraz Lubiszyn-3k bis. Uzyskany charakter krzywych w układzie PT jest bardzo do siebie zbliżony, zarówno w przedziale

Tablica 1. Zebrane parametry i uzyskane wyniki warunków ciśnienia i temperatury depozycji stałej fazy parafinowej WAT

\begin{tabular}{|c|c|c|c|c|}
\hline \multicolumn{2}{|c|}{ Temperatura WAT } & \multirow{2}{*}{$\begin{array}{l}\text { Ciśnienie } \\
\text { nasycenia }\end{array}$} & \multirow{2}{*}{$\begin{array}{l}\text { Ciśnienie } \\
\text { badania }\end{array}$} & \multirow{3}{*}{ Uwagi } \\
\hline Buszewo-1 & Lubiszyn-3k bis & & & \\
\hline$\left[{ }^{\circ} \mathrm{C}\right]$ & {$\left[{ }^{\circ} \mathrm{C}\right]$} & [bar] & [bar] & \\
\hline 30,7 & 35,7 & 1,01 & 20 & badanie próbki ropy martwej \\
\hline 26,5 & 37,1 & 50 & 70 & \\
\hline 25,3 & 35,5 & 100 & 120 & \\
\hline 25,5 & 35,1 & 150 & 170 & \\
\hline 25,9 & 34,8 & 200 & 220 & \\
\hline 26,8 & 35,2 & 200 & 250 & \multirow{4}{*}{ ciśnienie nasycenia niższe od ciśnienia badania } \\
\hline 27,8 & 36,0 & 200 & 300 & \\
\hline 28,5 & 36,5 & 200 & 350 & \\
\hline 29,3 & 37,5 & 200 & 400 & \\
\hline
\end{tabular}




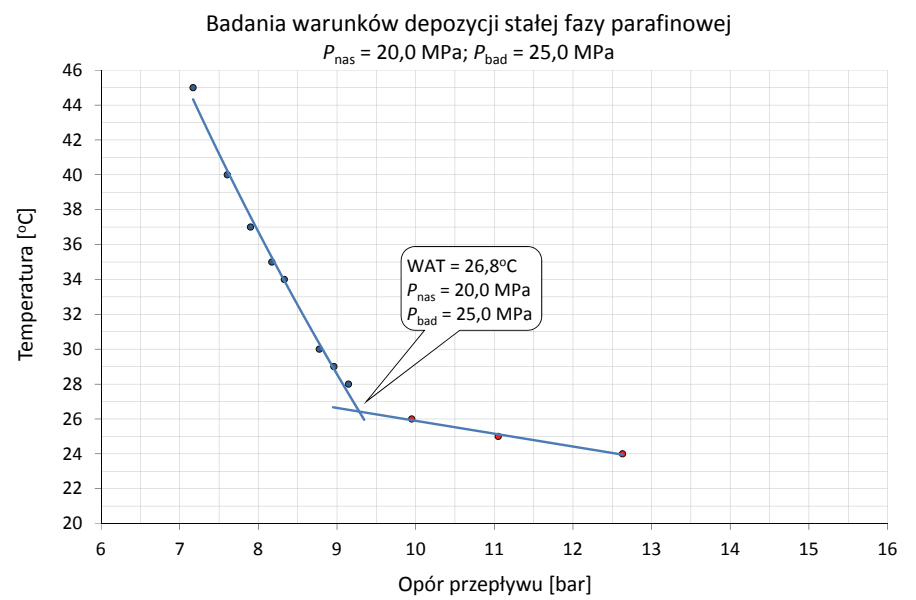

Rys. 6. Wpływ temperatury próbki ropy na opór przepływu wyznaczenie temperatury początku depozycji stałej fazy parafinowej

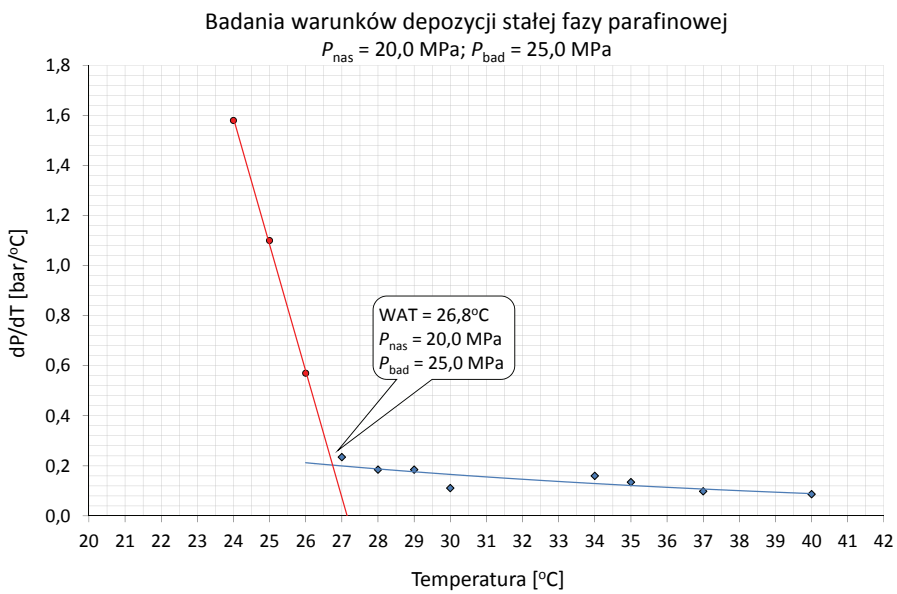

Rys. 7. Przyrost oporów przepływu przez kapilarę badanej próbki ropy w funkcji temperatury

poniżej, jak i powyżej ciśnienia nasycenia. Dla ropy z Lubiszyna WAT jest blisko o $10^{\circ} \mathrm{C}$ wyższy niż w przypadku ropy z Buszewa. W dalszej części artykułu opisane zostały badania mające na celu sprawdzenie masy osadu, jaki zostanie wychwycony w trakcie przetłaczania przez układ filtrujący. Eksperymenty te zostały przeprowadzone w warunkach PT znajdujących się w obszarze parafinowym.

Rys. 8. Obszar PT wytrącania parafiny dla ropy z Buszewa i Lubiszyna wyznaczony eksperymentalnie

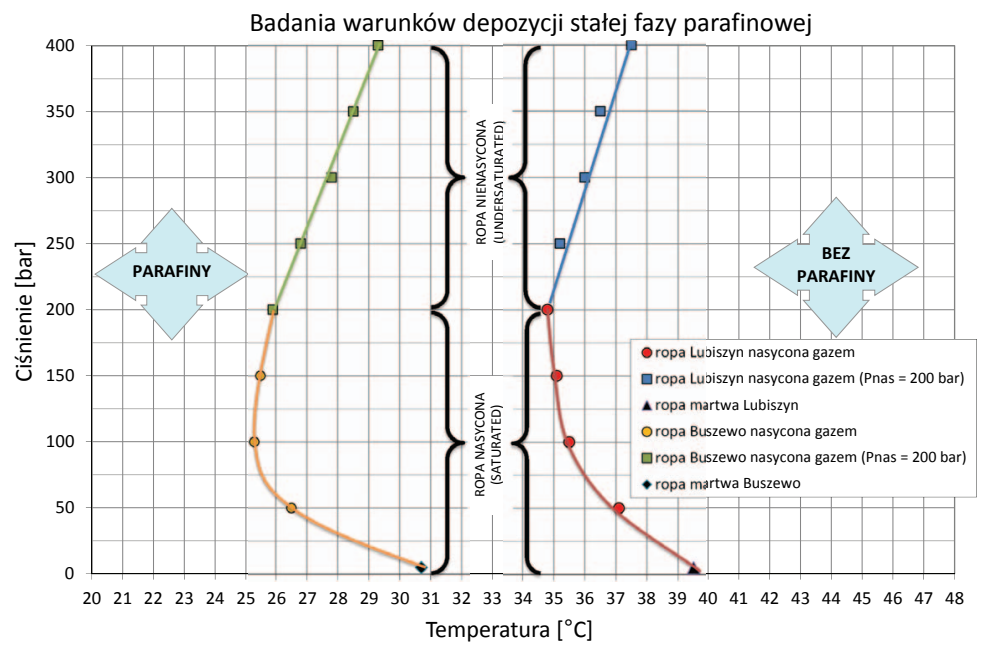

\section{Separacja osadów w zadanych warunkach ciśnienia i temperatury - wyznaczenie krzywej WPC}

W celu określenia potencjału parafinowania dla ropy z Buszewa oraz Lubiszyna dokonano modyfikacji zestawu badawczego służącego do wyznaczania temperatury punktu WAT. W tym celu układ filtrujący zastąpił poprzednio zamontowaną kapilarę. Filtr wraz z obudową i zespołem połączeń zanurzono w ciekłej łaźni termostatycznej kriostatu (rysunek 9).

Do odseparowania z ropy wytrąconego w danych warunkach osadu parafinowego skonstruowano specjalistyczny wysokociśnieniowy układ filtrujący (rysunek 10). Do jego wykonania wykorzystano między innymi wymienny filtr

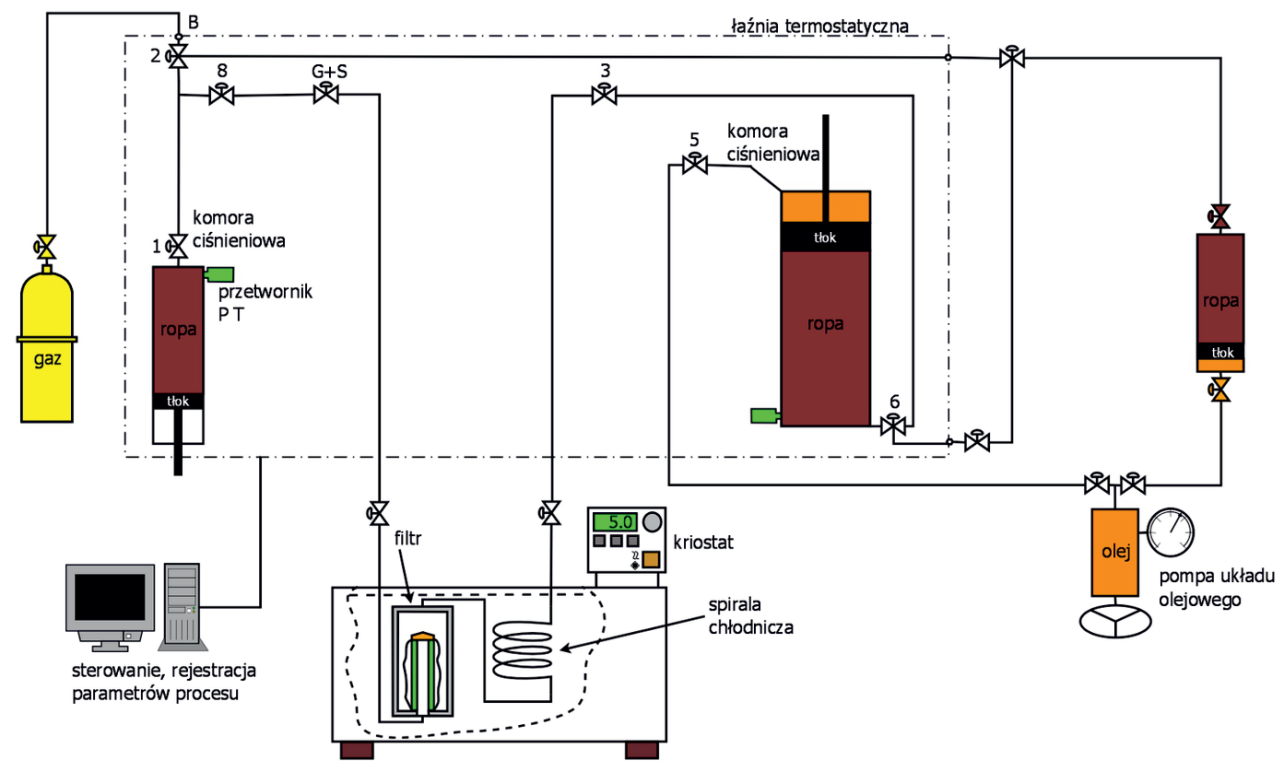

Rys. 9. Aparatura PVT dostosowana do odseparowania z ropy stałej fazy parafinowej w zadanych warunkach ciśnienia i temperatury 


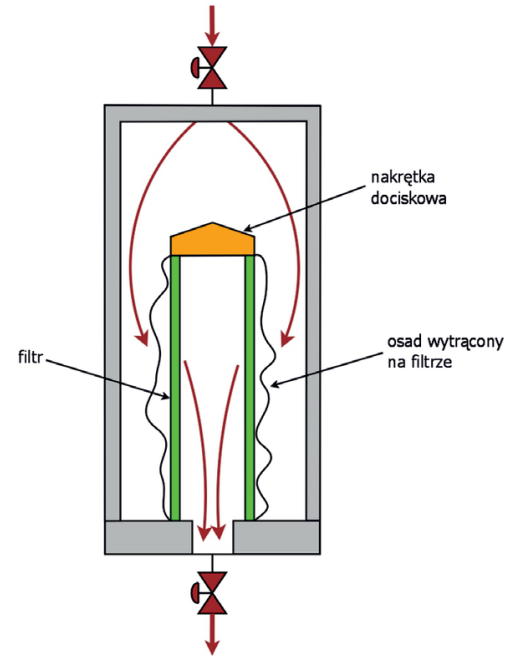

Rys. 10. Budowa filtra wychwytującego zdeponowany osad parafinowy

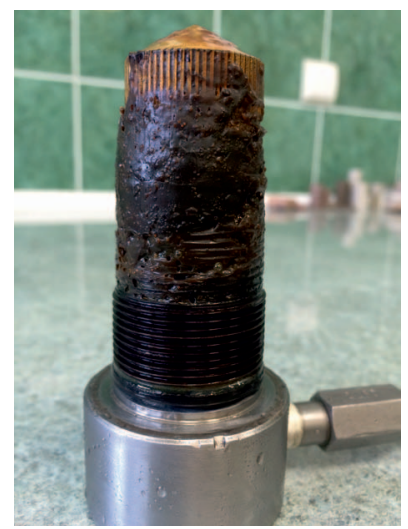

Fot. 1. Widok wychwyconego osadu na powierzchni filtra dla próbki ropy z Buszewa

Tablica. 2. Zebrane wyniki i badania potencjału parafinowania wraz ze spadkiem temperatury

\begin{tabular}{|c|c|c|c|c|c|}
\hline \multirow{3}{*}{ Ropa } & Temperatura & $\begin{array}{c}\text { Udział } \\
\text { procentowy }\end{array}$ & $\begin{array}{c}\text { Masa } \\
\text { osadu }\end{array}$ & $\begin{array}{c}\text { Gęstość ropy } \\
\text { po filtrowaniu }\end{array}$ & $\begin{array}{c}\text { Objętość } \\
\text { przetłoczonej ropy } \\
\text { na } 1 \text { g osadu }\end{array}$ \\
\hline \multirow{3}{*}[-]{} & {$\left[{ }^{\circ} \mathrm{C}\right]$} & {$[\%]$} & {$[\mathrm{g}]$} & {$\left[\mathrm{g} / \mathrm{cm}^{3}\right]$} & {$\left[\mathrm{cm}^{3}\right]$} \\
\hline & 5 & 1,87 & 1,53 & 0,8226 & 65 \\
\cline { 2 - 6 } & 10 & 0,92 & 0,75 & 0,8229 & 133 \\
\cline { 2 - 6 } & 15 & 0,58 & 0,48 & 0,8235 & 209 \\
\cline { 2 - 6 } & 20 & 0,37 & 0,31 & 0,8238 & 327 \\
\cline { 2 - 6 } & 25 & 0,22 & 0,18 & 0,8239 & 560 \\
\hline \multirow{5}{*}{ Lubiszyn-3k bis } & 30 & 0,07 & 0,08 & 0,8242 & 1836 \\
\cline { 2 - 6 } & 5 & 6,44 & 3,72 & 0,8209 & 28 \\
\cline { 2 - 6 } & 10 & 4,32 & 2,47 & 0,8214 & 49 \\
\cline { 2 - 6 } & 15 & 2,47 & 1,47 & 0,8223 & 69 \\
\cline { 2 - 6 } & 20 & 1,77 & 1,06 & 0,8229 & 124 \\
\cline { 2 - 6 } & 25 & 0,98 & 0,57 & 0,8242 & 026 \\
\hline
\end{tabular}

(odporny na oddziaływanie węglowodorów), zabudowany w wytrzymałej, stalowej, kompaktowej obudowie.

Proces odseparowania fazy parafinowej z próbki ropy z Buszewa oraz Lubiszyna przebiegał $\mathrm{w}$ temperaturach od $5^{\circ} \mathrm{C}$ do $30^{\circ} \mathrm{C}$ w krokach co $5^{\circ} \mathrm{C}$. Do tego celu użyto ropy nasyconej do ciśnienia 50 bar - w czasie badania $\mathrm{w}$ komorach ciśnieniowych badany płyn utrzymywano pod ciśnieniem około 70 bar. W każdej temperaturze przez układ filtrujący przetłoczono około $100 \mathrm{~cm}^{3}$ ropy z Lubiszyna oraz $70 \mathrm{~cm}^{3}$ ropy z Buszewa.

W zadanych warunkach PT na filtrze $5 \mu \mathrm{m}$ z przetłoczonej objętości ropy z Buszewa udało się odfiltrować od 0,08 g w $30^{\circ} \mathrm{C}$ do $3,74 \mathrm{~g} \mathrm{w} 5^{\circ} \mathrm{C}$ stałej fazy parafinowej, dla ropy z Lubiszyna wydzielono od $0,07 \mathrm{~g} \mathrm{w} 30^{\circ} \mathrm{C}$ do $1,53 \mathrm{~g} \mathrm{w} 5^{\circ} \mathrm{C}$. Osad charakteryzował się czarnym zabarwieniem, mazistą, tłustą konsystencją i dość intensywnym zapachem, charakterystycznym dla rop zasiarczonych z dolomitu głównego (fotografia 1).

Na rysunkach 11 i 12 przedstawiono otrzymane wyniki badań dwóch przebadanych próbek ropy, które przetłoczono przez układ filtrujący. Przebadane ropy w temperaturze $30^{\circ} \mathrm{C}$ wykazują niemalże identyczne masy osadu parafinowego. Dla temperatur w zakresie od $5^{\circ} \mathrm{C}$ do $25^{\circ} \mathrm{C}$ odseparowanego osadu jest już ponad 3-krotnie więcej w ropie z Buszewa. Na podstawie uzyskanych wyników WAT (rysunek 8) można było

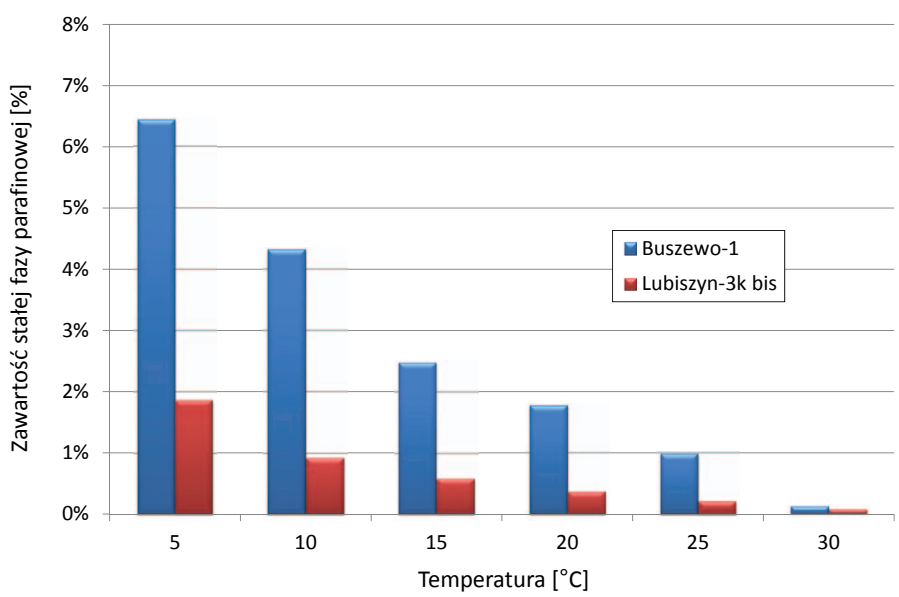

Rys. 11. Przyrost zawartości osadu parafinowego odseparowanego z ropy z odwiertów Buszewo-1 i Lubiszyn-3k bis uzyskanego w przeliczeniu na $1 \mathrm{dm}^{3}$ ropy w zadanej temperaturze

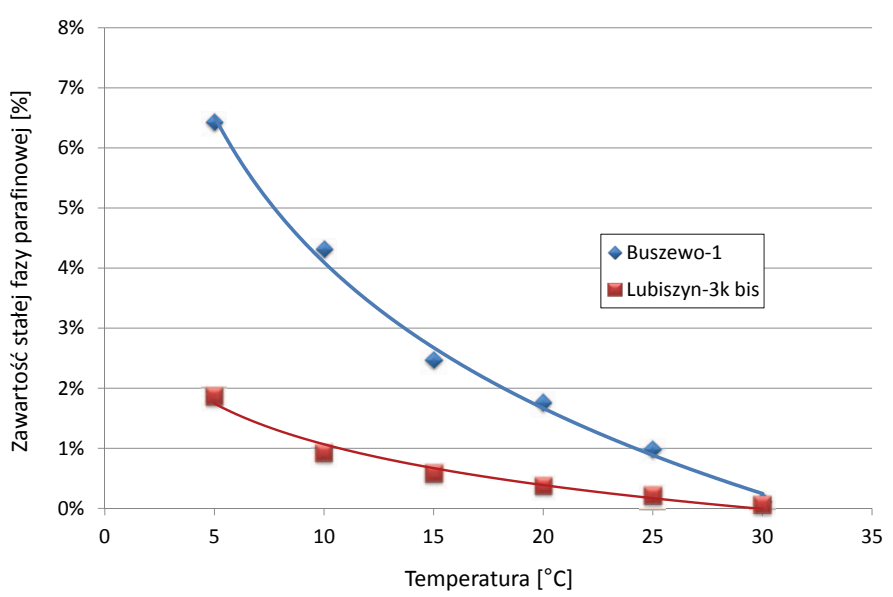

Rys. 12. Przebieg krzywych WPC dla ropy z odwiertów Buszewo-1 i Lubiszyn-3k bis 
przypuszczać, że otrzymane wyższe temperatury depozycji stałej fazy parafinowej dla ropy z Lubiszyna dadzą również większe ilości osadu w niższych temperaturach. Okazuje się jednak, że to ropa z Buszewa, mimo o blisko $10^{\circ} \mathrm{C}$ niższej temperatury WAT, zawiera kilkukrotnie więcej stałej fazy parafinowej w tych samych temperaturach co ropa z Lubiszyna.

\section{Podsumowanie}

Dokonano rozbudowy posiadanej bezrtęciowej aparatury PVT pod kątem badań warunków depozycji stałej fazy parafinowej, uzupełniając ją o możliwość określania potencjału parafinowania w funkcji spadku temperatury, pozwoliło to na wykreślenie krzywej WPC.

Wykorzystano możliwości posiadanej aparatury do wykonania rekombinacji badanej próbki ropy do dowolnych parametrów ciśnienia i temperatury. Opracowana metodyka wykorzystuje specjalnie do tego celu skonstruowany układ filtrujący, przez który przetłaczana jest zrekombinowana próbka ropy. Badanie to wykonuje się po wcześniejszym określeniu temperatury WAT, by separacje osadu parafinowego prowadzić w obszarze, w którym istnieje ryzyko depozycji stałej fazy parafinowej.

Ciśnienie i rozpuszczony w próbce ropy gaz mają wpływ na uzyskiwane wyniki WAT. Badania wykonane na próbkach ropy martwej dały wynik o ponad $4^{\circ} \mathrm{C}$ wyższy od wyników otrzymanych w przypadku próbek nasyconych gazem. Spadek ciśnienia powoduje zmniejszenie rozpuszczalności gazu w ropie i jego przejście z fazy stałej do gazowej. Prowadzi to do spadku rozpuszczalności parafiny w cieczy węglowodorowej i w konsekwencji do jej wytrącania. Udowodnione to zostało w przeprowadzonych seriach pomiarowych, w których wzrost ilości rozpuszczonego gazu dla badanej próbki ropy wpłynął na obniżenie WAT, ale tylko do ciśnienia 100 bar. W przypadku wyższych ciśnień zaobserwowano większy wpływ przyrostu ciśnienia w stosunku to zwiększającej się ilości rozpuszczonego gazu. Sprężanie ropy nienasyconej powoduje szybsze wytrącanie parafin. Obliczono, że przy zachowaniu stałego ciśnienia nasycenia badanej próbki ropy wartość WAT wzrasta o $1,35^{\circ} \mathrm{C}$ dla ropy $\mathrm{z}$ Lubiszyna oraz o $1,7^{\circ} \mathrm{C}$ dla ropy z Buszewa na każde 100 bar przyrostu ciśnienia.

Czynnik temperaturowy odgrywa kluczową rolę w wytrącaniu parafin, gdyż ich rozpuszczalność w płynach złożowych zmniejsza się wraz ze spadkiem temperatury. Silną zależność wytrącania parafin od temperatury doskonale ukazuje otrzymany diagram TP (rysunek 8), na którym wyznaczona została granica rozdzielająca obszar parafinowy (występowanie parafin w fazie stałej) od obszaru bez parafiny. Uzyskany charakter krzywych dla ropy z Buszewa oraz Lubiszyna w układzie PT jest bardzo do siebie podobny zarówno w przedziale poniżej, jak i powyżej ciśnienia nasycenia. Dla ropy z Lubiszyna depozycja stałej fazy parafinowej jest o blisko $10^{\circ} \mathrm{C}$ wyższa niż w przypadku ropy z Buszewa.

Po wykonaniu eksperymentów wychwytywania zdeponowanej stałej fazy parafinowej okazuje się, że to ropa z Buszewa, o niższej wartości temperatury WAT, zawiera kilkukrotnie więcej parafiny w fazie stałej. Otrzymane wyniki potwierdzają doniesienia terenowe, według których problemy w przepływie ropy z separatora do ośrodka zbiorczego dla ropy z Buszewa zaczynają się poniżej $20^{\circ} \mathrm{C}$, z kolei dla ropy z Lubiszyna poniżej $5^{\circ} \mathrm{C}$. Analizując przebieg krzywej WPC (rysunek 12) oraz biorąc pod uwagę informacje kopalniane, można zauważyć, że po przekroczeniu 2\% zawartości parafiny w fazie stałej zaczynają się problemy z osadzaniem związków parafinowych na ściankach rurociągu.

Są to pierwsze tego typu badania, które umożliwiają określenie ilości wytrąconej stałej fazy parafinowej w badanej próbce ropy, a następnie wykreślenie krzywej WPC. Połączenie pomiaru temperatury WAT, uwzględniające wpływ ciśnienia i rozpuszczonego gazu na badany proces, oraz potencjału parafinowania w funkcji spadku temperatury stanowi zestaw pomiarów, który pozwala określić zarówno to, kiedy rozpoczyna się wytrącanie stałej fazy parafinowej, jak i jej ilość w badanej próbce ropy. Opracowane sposoby badań umożliwiają określenie skuteczności inhibitorów parafin w dowolnych warunkach ciśnienia i temperatury oraz ustalenie ich optymalnej dawki.

Prosimy cytować jako: Nafta-Gaz 2018, nr 10, s. 759-767, DOI: 10.18668/NG.2018.10.08

Artykuł nadesłano do Redakcji 15.01.2018 r. Zatwierdzono do druku 3.04.2018 r.

Artykuł powstał na podstawie pracy statutowej pt.: Badania laboratoryjne określajace wzrost potencjału parafinowania wraz ze spadkiem temperatury - praca Instytutu Nafty i Gazu - Państwowego Instytutu Badawczego na zlecenie Ministerstwa Nauki i Szkolnictwa Wyższego; numer zlecenia: 44/KB/17, numer archiwalny: DK-4100-31/17. 


\section{Literatura}

[1] Alcazar-Vara L.E., Buenrostro-Gonzalez E.: Characterization of the wax precipitation in Mexican crude oils. Energy \& Fuels 2011, vol. 92, nr 4, s. 2366-2374.

[2] Bęben D.: Ochrona rurociagów przed wytracaniem się parafiny z ropy naftowej. Nafta-Gaz 2014, nr 10, s. 684-689.

[3] Correra S., Fasano A., Fusi L., Primicerio M.: Modelling wax diffusion in crude oils: The cold finger device. Applied Mathematical Modelling. Applied Mathematical Modelling 2006, vol. 31, nr 10, s. 2286-2298.

[4] Coto B., Martos C., Pena J.L., Espada J.J., Robustillo M.D.: A new method for the determination of wax percepitation from non-diluted crude oils by fractional precipitation. Fuel 2008, vol. 87, nr 10-11, s. 2090-2094.

[5] Coutihno J.A.P., Dardion J.L.: The limitations of the cloud point measurement techniques and the influence of the oil composition on its detection. Petroleum Science and Technology 2005, vol. 23, nr 9-10, s. 1113-1128.

[6] Dantas N.A.A., Gomes E.A.S., Barros N.E.L., Dantas T.N.C., Moura C.P.A.M.: Determination of Wax Appearance Temperature (WAT) in paraffin/solvent systems by photoelectric signal and viscosity. Brazilian Journal of Petroleum and Gas 2009, vol. 3, nr 4, s. 149-157.

[7] Elsharkawy A.M., Al-Sathhaf T.A., Fanhim M.A.: Wax deposition from Middle East crudes. Fuel 2000, vol. 79, nr 9, s. $1047-1055$.

[8] Huang Z., Zheng S., Fogler S.: Wax Deposition: Experimental Characterisations, Theoretical Modeling, and Field Practices. Taylor \& Francis 2007.

[0] Ijeomah C.E., Dandekar A.Y., Chukwu G.A., Khataniar S., Patil S.L., Baldwin A.L.: Measurement of wax appearance temperature under simulated pipeline (dynamic) condition. Energy \& Fuels 2008, vol. 22, nr 4, s. 2437-2442.

[10] Jeirani Z., Lashanizadegan A., Ayatollahi S., Javanmardi J.: The Possibility of Wax Formation in Gas Fields: a Case Study. Journal of Natural Gas Chemistry 2007, vol. 16, nr 3, s. 293-300.
[11] Kruka V.R., Cadena E.R., Long T.E.: Cloud point determination form crude oils. Society of Petroleum Engineers 1995, vol. 47, nr 8, s. 681-687.

[12] Lubaś J., Biały E., Warnecki M.: Asfalteny w problematyce wydobycia ropy naftowej. Prace Naukowe Instytutu Nafty i Gazu 2012, nr 179.

[13] Lubaś J., Biały E., Warnecki M.: Warunki depozycji stałej fazy parafinowej $i$ sposoby jej zapobiegania podczas eksploatacji złóż ropy naftowej. Prace Instytut Górnictwa Naftowego i Gazownictwa 1999, nr 100.

[14] Martos C., Coto B., Pena J.L., Espada J.J., Robustillo M.D.: Experimental determination and characterization of wax fractions precipitated as a function of temperatura. Energy \& Fuels 2008, vol. 22, nr 2, s. 708-704.

[15] Musser B.J., Kilpatrick P.K.: Molecular Characterization of Wax Isolated from a Variety of Crude Oils. Energy \& Fuels 1998, vol. 12, nr 4, s. 715-725.

[16] Pajda M., Gaździk B.: Wpływ środków powierzchniowo czynnych o działaniu dyspergującym na właściwości fizykochemiczne i funkcjonalne inhibitorów parafin do wysokoparafinowych rop naftowych. Nafta-Gaz 2013, nr 4, s. 319-328.

[17] Roehner R.M., Hanson F.V.: Determination of wax precipitation temperature and amount of precipitated solid wax versus temperature for crude oils using FT-IR spectroscopy. Energy \& Fuels 2001, vol. 15, nr 3, s. 756-763.

[18] Ronningsen H.P., Bjamdal B., Hansen A.B., Pedersen W.B.: Wax precipitation from North Sea crude oils. 1. Crystallization and dissolution temperatures, and Newtonian and non-Newtonian flow properties. Fuel 1991, vol. 5, nr 6, s. 895-908.

[19] Snyder R., Hallmark V.M., Strauss H.L., Maroncelli M.: Temperature and phase behavior of infrared intensities. The Journal of Physical Chemistry 1986, vol. 90, nr 22, s. 5623-5630.

[20] Szuflita S., Kuśnierczyk J.: Badanie wpływu ciśnienia i temperatury na proces wytracania parafin $w$ ropie naftowej. Nafta-Gaz 2017, nr 6, s. 395-404, DOI: 10.18668/NG.2017.06.04.

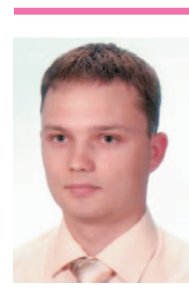

Mgr inż. Sławomir SZUFLITA

Asystent w Zakładzie Badania Złóż Ropy i Gazu Instytut Nafty i Gazu - Państwowy Instytut Badawczy ul. Lubicz 25 A

31-503 Kraków

E-mail: slawomir.szuflita@inig.pl

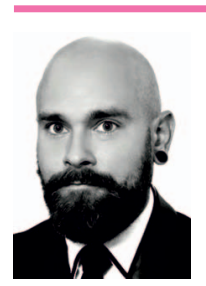

Mgr inż. Mirosław WOJNICKI

Asystent w Zakładzie Badania Złóż Ropy i Gazu

Instytut Nafty i Gazu - Państwowy Instytut Badawczy ul. Lubicz 25 A

31-503 Kraków

E-mail: miroslaw.wojnicki@inig.pl

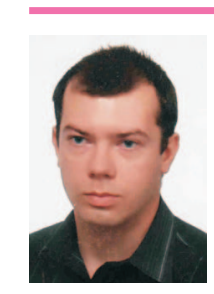

Mgr inż. Jerzy KUŚNIERCZYK

Specjalista badawczo-techniczny w Zakładzie

Badania Złóż Ropy i Gazu

Instytut Nafty i Gazu - Państwowy Instytut Badawczy ul. Lubicz 25 A

31-503 Kraków

E-mail: jerzy.kusnierczyk@inig.pl

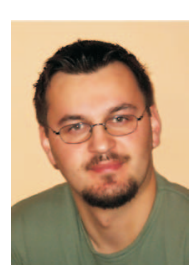

Dr inż. Marcin WARNECKI

Kierownik Zakładu Badania Złóż Ropy i Gazu Instytut Nafty i Gazu - Państwowy Instytut Badawczy ul. Lubicz 25 A

31-503 Kraków

E-mail: marcin.warnecki@inig.pl 